\title{
Fault architecture in the Main Ethiopian Rift and comparison with experimental models: Implications for rift evolution and Nubia-Somalia kinematics
}

\author{
Andrea Agostini ${ }^{\text {a,1 }}$, Marco Bonini ${ }^{\text {b }}$, Giacomo Corti ${ }^{\text {b,* }}$, Federico Sani ${ }^{\text {a }}$, Francesco Mazzarini ${ }^{\mathrm{c}}$ \\ a Dipartimento di Scienze della Terra, Università degli Studi di Firenze, Via G. La Pira, 4, 50121 Florence, Italy \\ b CNR, Consiglio Nazionale delle Ricerche, Istituto di Geoscienze e Georisorse, U.O. Firenze, Via G. La Pira, 4, 50121 Florence, Italy \\ c Istituto Nazionale di Geofisica e Vulcanologia, Via della Faggiola 32, 56126 Pisa, Italy
}

\section{A R T I C L E I N F O}

\section{Article history:}

Received 8 February 2010

Received in revised form 21 September 2010

Accepted 14 November 2010

Available online 17 December 2010

Editor: Y. Ricard

\section{Keywords:}

continental rifting

East African Rift

Main Ethiopian Rift

rift kinematics

plate kinematics

\begin{abstract}
A B S T R A C T
The Main Ethiopian Rift (MER) offers a complete record of the time-space evolution of a continental rift. We have characterized the brittle deformation in different rift sectors through the statistical analysis of a new database of faults obtained from the integration between satellite images and digital elevation models, and implemented with field controls. This analysis has been compared with the results of lithospheric-scale analogue models reproducing the kinematical conditions of orthogonal and oblique rifting. Integration of these approaches suggests substantial differences in fault architecture in the different rift sectors that in turn reflect an along-axis variation of the rift development and southward decrease in rift evolution. The northernmost MER sector is in a mature stage of incipient continental rupture, with deformation localised within the rift floor along discrete tectono-magmatic segments and almost inactive boundary faults. The central MER sector records a transitional stage in which migration of deformation from boundary faults to faults internal to the rift valley is in an incipient phase. The southernmost MER sector is instead in an early continental stage, with the largest part of deformation being accommodated by boundary faults and almost absent internal faults. The MER thus records along its axis the typical evolution of continental rifting, from fault-dominated rift morphology in the early stages of extension toward magma-dominated extension during break-up. The extrapolation of modelling results suggests that a variable rift obliquity contributes to the observed along-axis variations in rift architecture and evolutionary stage, being oblique rifting conditions controlling the MER evolution since its birth in the Late Miocene in relation to a constant post ca. $11 \mathrm{Ma}$ $\sim$ N100E Nubia-Somalia motion.
\end{abstract}

(c) 2010 Elsevier B.V. All rights reserved.

\section{Introduction}

Continental rifting represents one of the most important geodynamical processes affecting the lithosphere-asthenosphere system. If successful, the process leads to continental break-up with typical evolution characterized by the progressive focusing of deformation in a narrow straining region that eventually evolves into oceanic spreading centres (e.g. Ziegler and Cloetingh, 2004).

The Main Ethiopian Rift (MER) has been suggested to be in the breakup stage and to record all the main different evolutionary stages (e.g. Corti, 2009; Ebinger, 2005), and thus is one of the few locations on Earth where the whole rifting progression can be analysed successfully. Geological and geophysical data have evidenced different MER sectors characterized by distinctive volcano-tectonic characters and geophysical signatures, inter-

\footnotetext{
* Corresponding author.

E-mail address: cortigi@geo.unifi.it (G. Corti).

1 Now at: Faculty of Earth and Life Sciences, VU University Amsterdam, De Boelelaan 1085, 1081 HV Amsterdam, The Netherlands.
}

preted as the expression of different stages in an evolutionary rift sequence (e.g. Bonini et al., 2005; Hayward and Ebinger, 1996). In particular, an overall north to south decrease in crustal thinning and tectono-magmatic modifications of the crust and lithosphere (e.g. Keranen and Klemperer, 2008), together with the southward increase in fault length and effective elastic thickness (Hayward and Ebinger, 1996), point to an along-axis variation in rift evolution.

In this study the fault architecture of the MER has been quantitatively characterized to define the spatial variation of rift evolution. We approached this problem by producing a new detailed fault database from satellite images and digital elevation model analysis. The data, verified during different field surveys, have been statistically analysed and compared with the results of lithosphericscale analogue models of orthogonal and oblique rifting. The results of this approach have allowed better characterizing the fault architecture in the MER, providing new constrains on the spatial variation of the rifting evolution in Ethiopia as well as new insights into the plate kinematics controlling the rift process. These results highlight the importance of rift obliquity on the extension process, and thus involve general implications for the evolutionary model of continental rifting. 


\section{Tectonic setting}

The MER is part of the East African Rift System (EARS), a region of rifting that accommodates the active extension between the Nubia and Somalia Plates (e.g. Corti, 2009; Ebinger, 2005). The MER extends from the Afar triple junction in the north, to the northern Kenya Rift to the south (Fig. 1).

The MER is traditionally differentiated into three main sectors differing in terms of rift trend, fault patterns and lithospheric characteristics (Fig. 1; e.g. Bonini et al., 2005; Hayward and Ebinger, 1996; Mohr, 1983): (1) the $\sim \mathrm{N} 50^{\circ}-55^{\circ} \mathrm{E}$-trending Northern MER (NMER), (2) the $\sim \mathrm{N} 30^{\circ}-40^{\circ} \mathrm{E}$ Central MER (CMER), and (3) the Southern MER (SMER) further subdivided into two sub-sectors: (3a) a $\sim \mathrm{N} 20^{\circ}-25^{\circ}$ E-trending northern sub-sector (SMERn) and (3b) a $\sim \mathrm{NO}^{\circ}-$ $10^{\circ} \mathrm{E}$-trending southern sub-sector (SMERs).

The different MER sectors are characterized by two distinct systems of normal faults that differ in terms of orientation, structural characteristics (e.g. length, vertical throw), timing of activation and

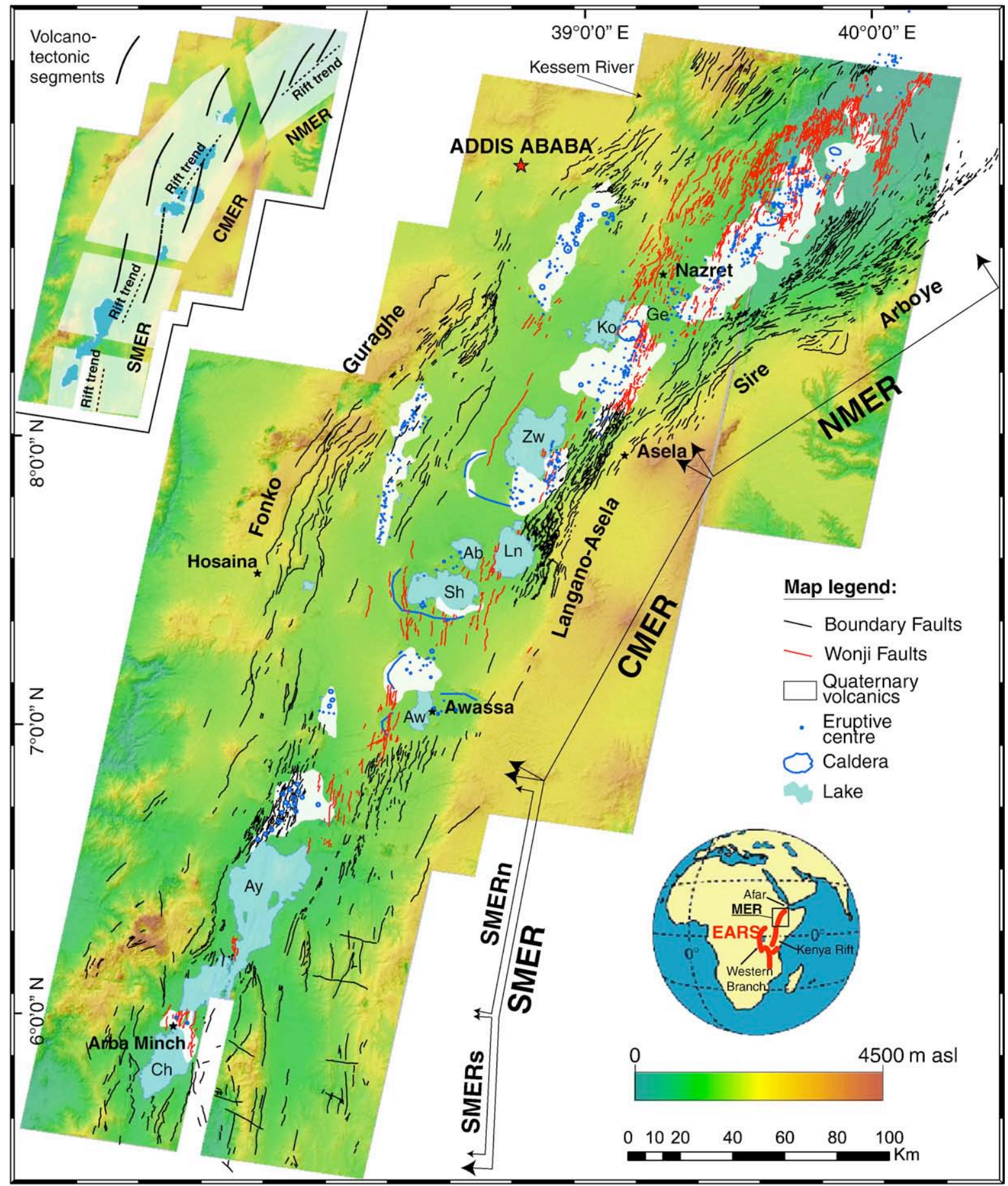

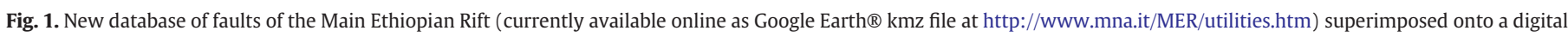

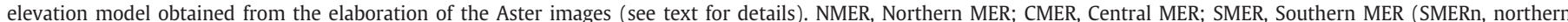

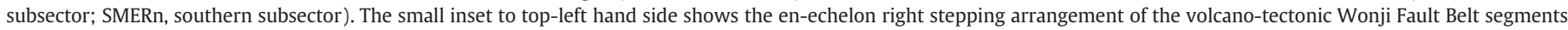

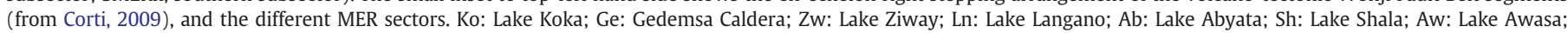
Ay: Lake Abaya; Ch: Lake Chamo. 
relation with magmatism: (1) the border faults and (2) a set of faults affecting the rift floor, usually referred to as Wonji Fault Belt (e.g., Boccaletti et al., 1998; Mohr, 1962).

The border faults are normally long, widely spaced, characterized by large vertical offset and variable orientation in the different MER sectors. The activation of these faults is diachronous along the rift axis; in the NMER it is commonly interpreted to have occurred in the Late Miocene ( $11 \mathrm{Ma}$; Wolfenden et al., 2004), to the Late Miocene-Early Pliocene in the CMER ( 6-8 Ma; Bonini et al., 2005; WoldeGabriel et al., 1990), and to the Plio-Pleistocene in the SMER, although here an earlier Early Miocene deformation phase has been suggested (e.g., Bonini et al., 2005; Ebinger et al., 1993; Woldegabriel et al., 1991). Geological data and analysis of the historical and instrumental seismicity suggest that the boundary faults are largely inactive and mostly eroded in the Northern MER (e.g., Casey et al., 2006; Keir et al., 2006; Wolfenden et al., 2004). Conversely, morphostructural and geological data together with the analysis of local seismicity suggests that the boundary faults are still accommodating some extensional deformation in the CMER and SMER (Gouin, 1979; Keir et al., 2006; Pizzi et al., 2006).

The Wonji Fault Belt (WFB) is a tectono-volcanic system characterized by short, closely spaced, active faults that exhibit minor vertical throw. The WFB faulting developed essentially in the last 2 My (e.g. Boccaletti et al., 1999; Ebinger and Casey, 2001) and was intimately associated with the intense Quaternary magmatism of the rift floor. These faults are well developed in the NMER, where the WFB structures form clearly defined right-stepping en-echelon segments obliquely cutting the rift floor. The occurrence of this fault system decreases southwards (see Section 3). Magma intrusion occurs throughout the lithosphere below the WFB (e.g. Keir et al., 2005; Kendall et al., 2005). Segmented high velocity anomalies, interpreted as regions of mafic intrusion in the mid-upper crust beneath the MER axis (Daly et al., 2008), are spatially coincident with the segmentation of the rift axis interpreted from the surface expression of faulting and Quaternary volcanism (e.g., Abebe et al., 2005, 2007; Ebinger and Casey, 2001; Hayward and Ebinger, 1996; Mohr, 1962). These observations allow considering the WFB as distinct tectono-magmatic segments within the rift depression (e.g. Beutel et al., 2010; Ebinger and Casey, 2001; Keranen et al., 2004).

The main MER sectors also show marked differences in lithospheric and tectono-magmatic characteristics. Recent geophysical data suggest an overall decrease in crustal thinning and tectonomagmatic modifications of the crust and lithosphere proceeding from the NMER southwards (e.g. Keranen and Klemperer, 2008).

The evolution of the different MER sectors has been controlled by the long-term Nubia-Somalia kinematics, which is currently constrained by geodetic and seismic data at $\sim \mathrm{N} 100^{\circ} \mathrm{E}$ average extension vector (e.g. Bendick et al., 2006; Keir et al., 2006; Stamps et al., 2008). Analysis of slip data on Quaternary faults corroborates this extension direction (Bonini et al., 2005; Pizzi et al., 2006), which can be reliably extrapolated up to 3.2 Ma according to plate kinematic models (Chu and Gordon, 1999). The pre 3.2 Ma kinematics is less constrained and models of constant or variable direction of extension over the past 11 My have been proposed (e.g. Corti, 2009).

Nevertheless, the post 3.2 Ma extension direction is not orthogonal to the rift axis, and the MER can thus be regarded as an oblique rift (Bonini et al., 1997). This condition may be related to the localisation of extensional deformation along a N- to NE-SW-trending lithosphericscale pre-existing heterogeneity (Bastow et al., 2008; Corti, 2008; Keranen and Klemperer, 2008; Keranen et al., 2009). This lithospheric weakness zone corresponds to a Neoproterozoic suture zone separating two distinct Proterozoic basement terranes underlying the Ethiopian and Somalian plateaus, as evidenced by mapping of ophiolitic fragments, Neodymium (Nd) isotopic data, SKS splitting patterns and differences in crustal and mantle properties between the eastern and western rift flanks (Corti, 2009; Keranen and Klemperer, 2008 and references therein). The suture zone in the MER is composed of different sectors that trend at variable obliquity angles to the regional stretching vector, thus making this rift a favourable setting for understating the influence of weakness zones on the oblique rifting processes.

\section{Fault analysis}

\subsection{Data acquisition and methods}

In this work we present a new database of the faults affecting the whole MER. The faults were identified and mapped on a mosaic of 25 ASTER images (displayed as RGB false colour composites with band 3 in the red channel, band 2 in the green channel and band 1 in the blue channel; $15 \mathrm{~m} \times 15 \mathrm{~m}$ lateral resolution; Figs. 1, S1a) covering the entire area of interest, and on the associated digital elevation models ( $15 \mathrm{~m} \times 15 \mathrm{~m}$ lateral resolution, extracted from the orthogonal stereoscopic pair of ASTER channels 3N and 3B; Figs. 1, S1a).

In these images, fault traces were identified by the change in pixel opacity and by the characteristic nearly linear shape compared to the other geomorphologic elements (e.g. Soliva and Schultz, 2008). Digital elevation models and slope maps (Fig. S1a) implemented the interpretation of fault traces, which were drawn at the base of their scarp (Fig. S1b). Fault traces were approximated with polyline features and digitized in a GIS environment to the UTM projection (zone 37N, datum WGS1984). Faults were distinguished as internal and border faults according to their position with respect to the rift depression and according to their geometrical characteristics (e.g. trend). The mapped data were integrated and verified with existing geological data (e.g. Abebe et al., 1999, 2005; Kazmin, 1978; Le Turdu et al., 2005). The reliability of our database was also tested during three different field surveys in 2007-2009.

Fault traces were analysed quantitatively in term of length, spacing, azimuth distribution and density. In order to analyze the fault azimuth distribution, the polyline features used to map the fault traces were transformed in tip-to-tip lines (a straight line joining the extreme points of a polyline feature, Fig. S1c). The tip-to-tip azimuth data were weighted for the length of the corresponding fault. The weighting factor for each fault was the ratio between its length and the minimum fault length in the whole data set (i.e., 100 m), such that long faults have higher ratios than short ones. The frequency of the azimuth of a tip-to-tip fault directly relates to this ratio: the longer the fault the higher its frequency. Fault density distribution (Fig. 2) has been derived using a grid oriented nearly parallel to the overall envelope of the fault network (approximately NE-SW) in order to attenuate border effects. The density has been calculated for $5 \mathrm{~km}$ sided square cells as the ratio between the cumulative length of faults contained in each cell and the area of the cell (Fig. 2).

This analysis allows the definition of the general fault pattern (in terms of spacing, length, density and fault trend), an information that has been demonstrated to be crucial and sufficient for determining the overall rift kinematics (e.g., Dauteuil and Brun, 1996). Other parameters, such as fault throw and kinematics - though important are normally more difficult to obtain over large areas and are not considered in this analysis. This type of fault pattern outcome has been often coupled with analogue models, providing the basis for a well-established approach that has been successfully applied to the determination of rift kinematics in oblique extension settings, such as submerged or exposed oceanic ridges (e.g., Dauteuil and Brun, 1996; Dauteuil et al., 2001) and continental rifts (e.g., Bonini et al., 1997; Brun and Tron, 1993; Corti, 2008).

\subsection{Results of the statistical fault analysis}

The remote sensing analysis allowed us to record 3302 structures (Table S1), spanning almost three orders of magnitude in length, from $\sim 100 \mathrm{~m}$ to the $75 \mathrm{~km}$-long Fonko fault on the western border of the Central MER (Fig. 1). These fault statistical analyses were carried out 


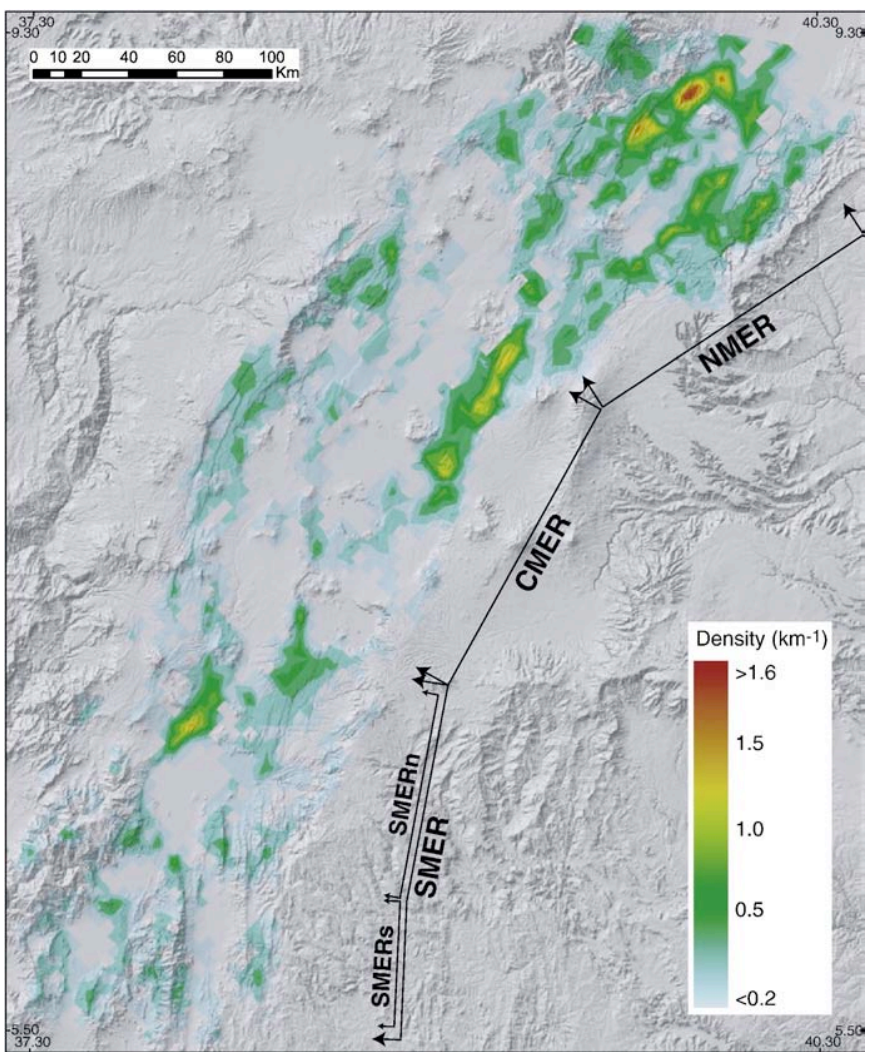

Fig. 2. Map of fault density distribution performed using the whole fault dataset (reported in Fig. 1) and superimposed onto a shaded relief of the study area. The density has been calculated for $5 \mathrm{~km}$-sided square cells as the ratio between the cumulative length of faults contained in each cell and the area of the cell, over a grid that is oriented nearly parallel to the overall envelope of the fault network (approximately NE-SW).

for each MER sector. The results are summarized in Table S1 and discussed later.

\subsubsection{Fault number, length and density}

In the NMER, the internal WFB faults, well organized in en-echelon segments, are higher in number than the border faults, being the border faults/internal faults ratio 0.57 . The border faults consist of long and spaced en-echelon structures (average length $1.80 \mathrm{~km}$, maximum length $\sim 25 \mathrm{~km}$, average spacing $1035 \mathrm{~m}$ ), whereas the internal faults are shorter (average length $1.26 \mathrm{~km}$, maximum length $\sim 15 \mathrm{~km}$ ) and more closely spaced (955 $\mathrm{m}$ on average). Fault density confirms that maximum values are obtained within the rift floor in correspondence to WFB segments (Fig. 2).

In the CMER and SMER, the border faults/internal faults ratio shows high values (4.38 and 5.20, respectively) thus manifesting the clear predominance of the border faults. These latter are longer (2.56 km and $2.64 \mathrm{~km}$ in the CMER and in the SMER, respectively) and more spaced $(1200 \mathrm{~m}$ and $1260 \mathrm{~m}$ in the CMER and SMER, respectively) compared with the northern sector (Table S1). The limited number of WFB faults in the CMER and SMER does not allow a meaningful statistical analysis. Qualitatively, the internal faults in the CMER and SMER sectors appear as short structures (only a few faults are longer than $10 \mathrm{~km}$ ) with small vertical separation (e.g. Boccaletti et al., 1998), resulting individually similar to those in the NMER. Nevertheless, the en-echelon arrangement of the NMER internal faults is not clearly detectable in the CMER and SMER, where internal faults are concentrated mainly near the rift margins, and only few of them affect the centre of the rift valley (Fig. 1). This is confirmed by analysis of fault density that, unlike the NMER, shows maximum values at the rift borders and comparatively lower values in the rift centre (Fig. 2).

In summary, a North to South increase in border fault length and a strong along-axis variation of the relative importance (in number and density) of internal and border faults can be highlighted. This in turn reflects a different distribution of the brittle deformation across the rift structure: in the NMER faulting affects primarily the rift depression with the well developed WFB, while deformation in the CMER and SMER is concentrated on the rift margins (see Section 4.3). This distribution is not altered by factors such as vegetation coverage (which is scarce and homogenously distributed throughout the MER) and occurrences of lakes (which occupy less than $5 \%$ of the NMER, less than $10 \%$ of CMER, and $\sim 10 \%$ of the SMER). Also, this analysis is independent from occurrence of recent volcanic products, which would tend to erase topography (i.e., the fault escarpments) and thus to apparently decrease fracture density: this latter is instead maximum where Quaternary volcanism is widespread as in the magmatic segments of the NMER.

\subsubsection{Fault azimuth}

Fault trace orientation was analysed in term of azimuthal distribution in the different rift sectors; the results are presented on $0^{\circ}-180^{\circ}$ histograms at $5^{\circ}$ intervals for each MER sector, and further subdivided into internal and border faults (Fig. 3).

In the roughly $\sim \mathrm{N} 50^{\circ}-55^{\circ}$-trending NMER, the total fault azimuth histogram shows a main peak trending between $\mathrm{N} 20^{\circ}$ and $\mathrm{N} 25^{\circ}$ (Fig. 3). This peak corresponds to the orientation of the WFB faults. The border faults are instead characterized by a main peak at $\sim \mathrm{N} 35^{\circ}-$ $40^{\circ}$, which is thus slightly oblique to the mean rift trend (Fig. 3 ).

The $\sim \mathrm{N} 30^{\circ}-40^{\circ}$-trending CMER shows a main peak varying between $\mathrm{N} 25^{\circ}$ and $30^{\circ}$, which corresponds to the border faults system that is slightly oblique to the mean rift trend likewise the NMER. The WFB faults in the CMER are statistically less evident than in the NMER (compare the height of the peaks in the corresponding histograms in Fig. 3) and exhibit a $\mathrm{N} 10^{\circ}-\mathrm{N} 15^{\circ}$-trending main peak.

The analysis of the fault distribution in the SMER considered the subdivision into the $\sim \mathrm{N} 20^{\circ}-25^{\circ}$-trending SMERn and the roughly $\sim \mathrm{N}^{\circ}-10^{\circ}$-trending SMERs. In the SMERn, the border faults show a main peak varying between $\mathrm{N} 20^{\circ}$ and $\mathrm{N} 25^{\circ}$, whereas this peak in the SMERs trends $\sim \mathrm{N} 10^{\circ}-15^{\circ}$ (Fig. 3 ). In both sub-sectors, the peaks of internal faults are oriented $\sim \mathrm{N} 10^{\circ}-15^{\circ}$, although they are less important (see Section 3.2.1). A secondary $\mathrm{N} 100^{\circ}$-N $105^{\circ}$-trending peak can be also detected in the SMERs histogram (Fig. 3).

The analysis of the fault azimuth distribution in the various MER sector histograms reveals that the angle between the internal and border faults decreases from the NMER $\left(\sim 20^{\circ}\right)$ southwards $\left(\sim 15^{\circ}\right.$ in CMER and SMERn), reaching a semi-parallelism between the two fault systems in the SMERs (Fig. S2). Similarly, the total span of fault orientations (i.e., the azimuth dispersion) is again at maximum in the NMER and decreases southwards (Fig. Fig. S2), as also testified by the decreasing trend of the standard deviation of the weighted fault azimuth distributions (Table S2).

\subsection{Analogue models}

In order to better understand and characterize the fault architecture in relation to the evolution of rifting and plate kinematics, the results of the remote sensing fault analysis have been compared with further elaboration and implementation of previous lithospheric scale analogue models of orthogonal and oblique continental rifting (Agostini et al., 2009).

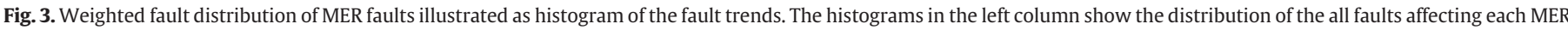

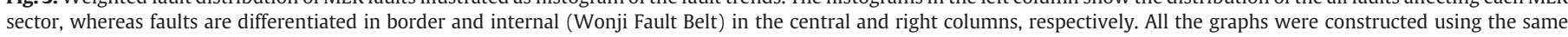
weighting factor (i.e., $100 \mathrm{~m}$ ), such that all the histograms are directly comparable each other. Abbreviations are as in Figure 1. 


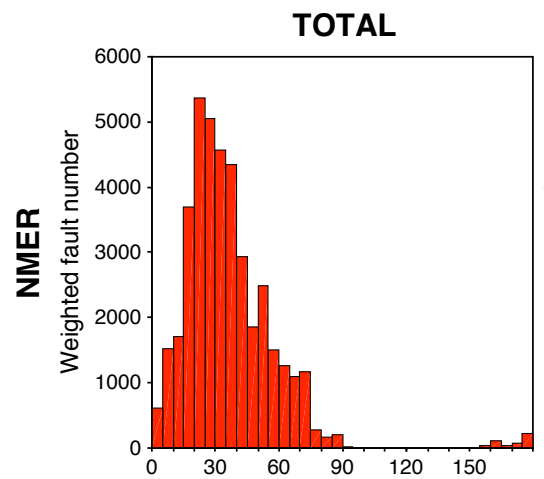

BORDER
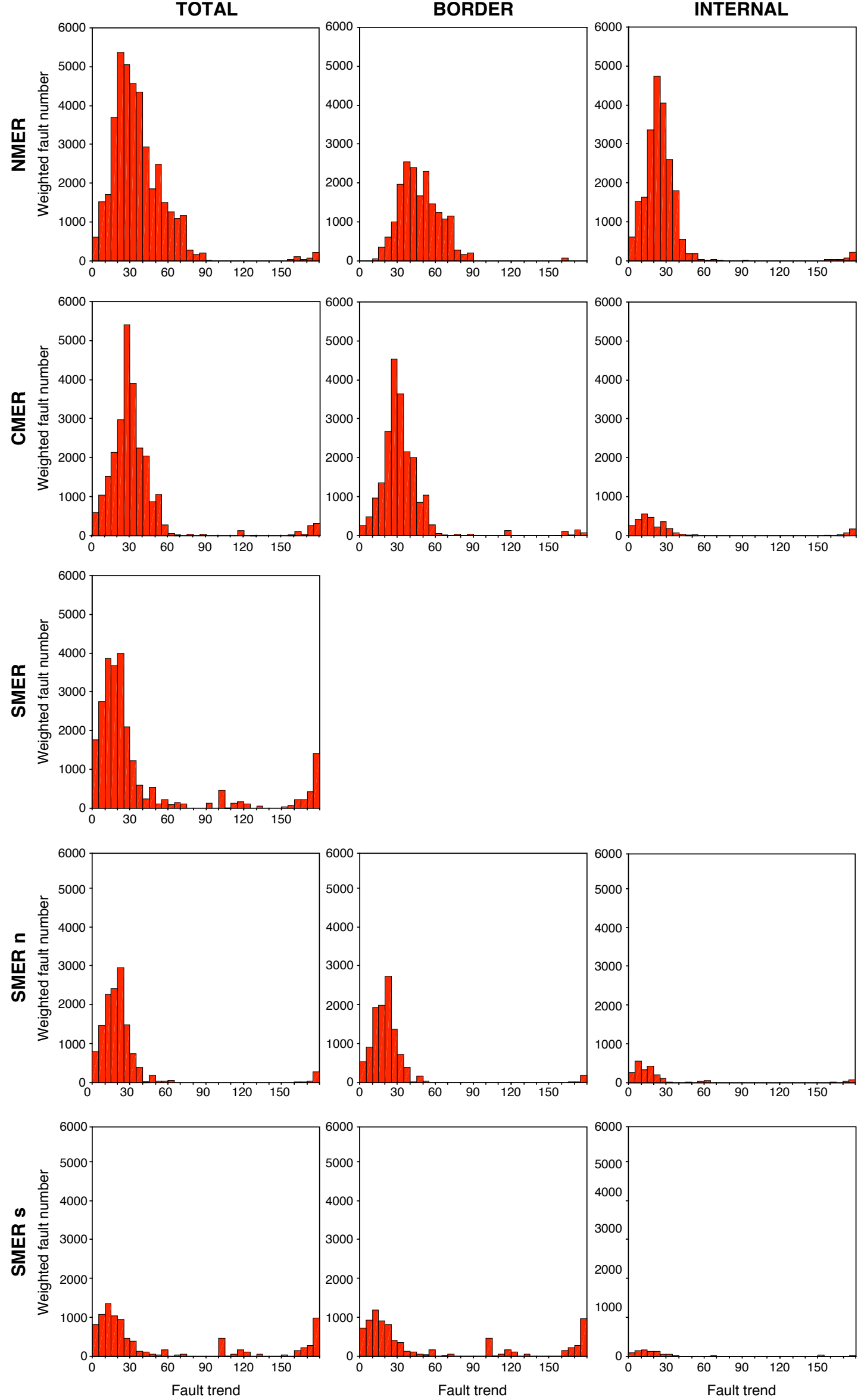
Analogue models were performed in an artificial gravity field of $\sim 18 \mathrm{~g}$ by using a large capacity centrifuge (Fig. S3). The models reproduced the extension of a $50 \mathrm{~km}$-thick continental lithosphere (crust + lithospheric mantle) floating above a low viscosity material simulating the asthenosphere (see Corti, 2008); the models were made of sand powder and silicone mixtures to reproduce the brittle and ductile behaviour of lithospheric layers. The experimental lithosphere contained a central weakness zone, analogous to the presence of a pre-existing weakness zone in nature that localizes deformation during progressive extension as the lithospheric suture imaged by geophysical data below the MER (see Section 2; Fig. S3). This weak zone was modelled by considering a local increase in crustal thickness (analogous to the presence of a pre-existing crustal root), which greatly reduces the integrated resistance of the lithosphere by (1) replacing the strong lithospheric mantle material with weaker crustal material and (2) increasing initial Moho temperatures and thus softening the crustal materials with respect to the surroundings (Fig. S3; see Agostini et al., 2009). Varying the orientation of this weakness with respect to the extension direction allowed controlling rift kinematics, particularly the obliquity angle $\alpha$ (i.e. the angle between the orthogonal to the pre-existing weakness and the extension direction; Fig. S3). The adopted model to nature length ratio was $6.7 \times 10^{-7}$, such that $1 \mathrm{~cm}$ in the model corresponded to $\sim 15 \mathrm{~km}$ in nature; dynamic-kinematic similarity ensured that the velocity of extension applied to the models $\left(\sim 10^{-4} \mathrm{~m} \mathrm{~s}^{-1}\right)$ scaled to natural values of $4-6 \mathrm{~mm} \mathrm{yr}^{-1}$. More details about the modelling approach, results and comparison with previous experimental works are extensively described in Agostini et al. (2009).

Here we summarize the four models that best fit the MER sectors in terms of fault pattern and rift architecture (see Section 4.1). These models vary from pure orthogonal extension $\left(\alpha=0^{\circ}\right)$, to low $\left(\alpha=15^{\circ}\right.$ and $\alpha=30^{\circ}$ ) and moderate obliquity $\left(\alpha=45^{\circ}\right)$.

In all the models, rift evolution consisted of two distinct evolutionary stages, each characterized by the development of a particular fault system. The first evolutionary stage (Stage 1 in Fig. 4a) was characterized by basin subsidence and activation of large, enechelon boundary faults parallel to the rift trend for $\alpha=0^{\circ}$, and slightly oblique for low to moderate obliquity (main orientation peak $\sim 10-15^{\circ}$ for $\alpha=15^{\circ}, \sim 15-20^{\circ}$ for $\alpha=30^{\circ}$, and $\sim 20^{\circ}-25^{\circ}$ for $\alpha=45^{\circ}$; Fig. 5). Antithetic faults developed in the rift depression defining a couple of marginal grabens (whose expression became less clear increasing $\alpha$ ) delimiting an undeformed rift floor. In this first stage all the deformation was accommodated along the rift margins by slip on the border and antithetic faults (Fig. 4b). As extension proceeded incipient faults appeared on the relatively undeformed rift depression (intermediate stage in Fig. 4a), testifying to a migration a Stage 1 - Boundary faults
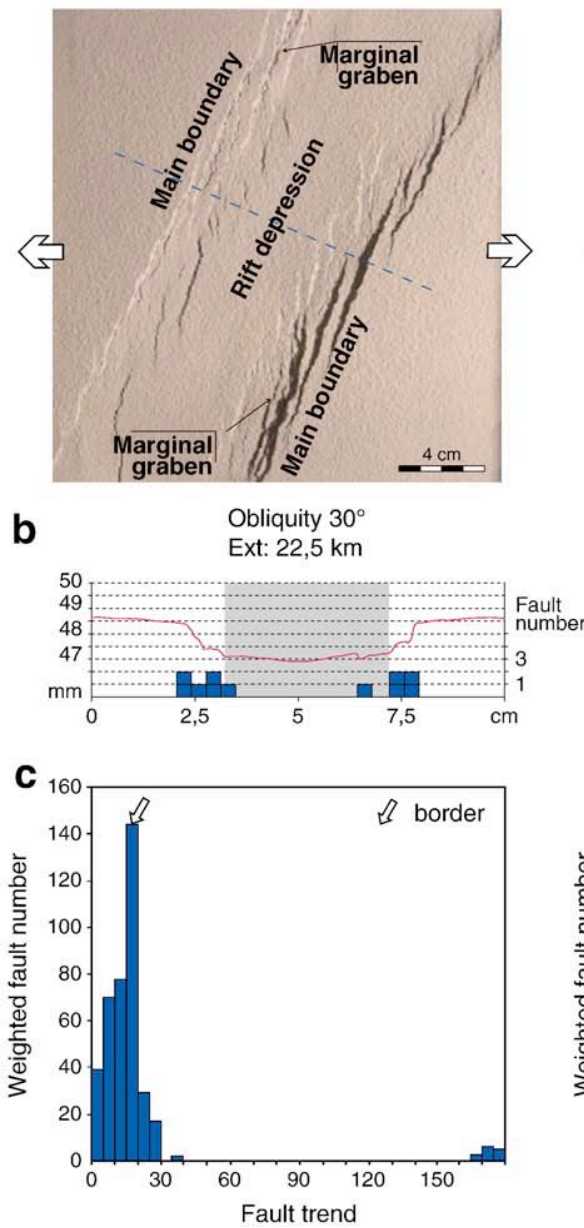

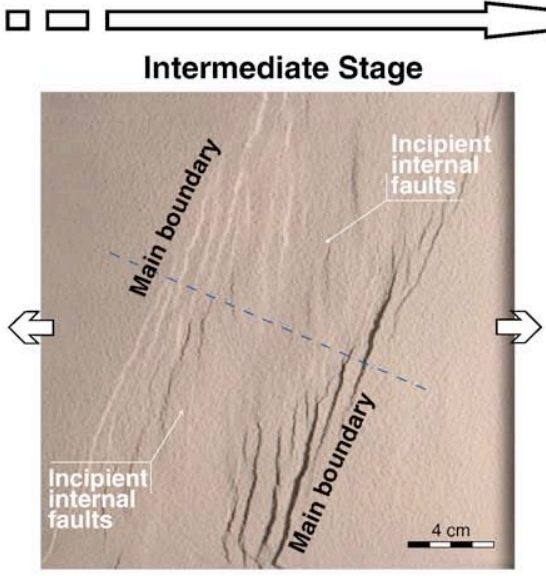

Obliquity $30^{\circ}$ Ext: $31,5 \mathrm{~km}$
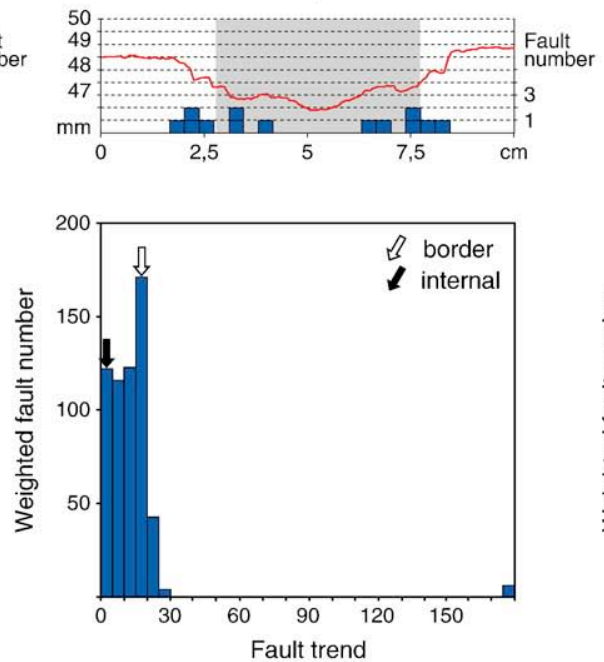

Stage 2 - Internal faults

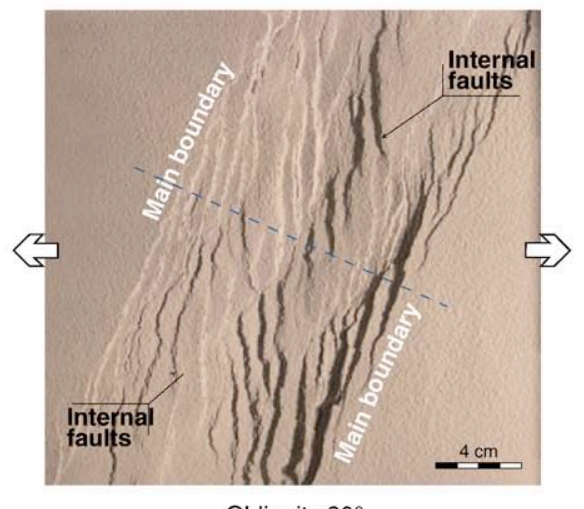

Obliquity $30^{\circ}$ Ext: 42 km
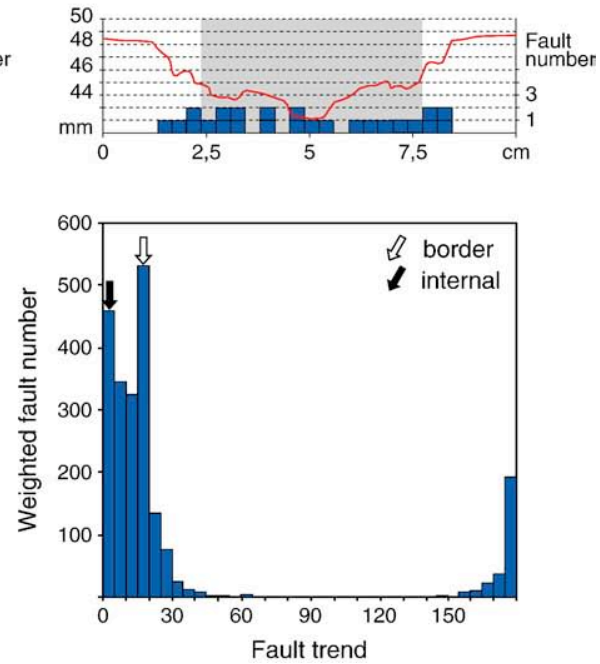

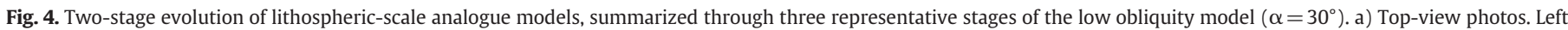

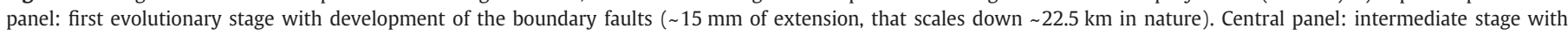

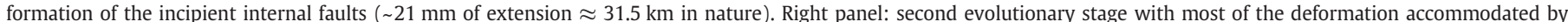

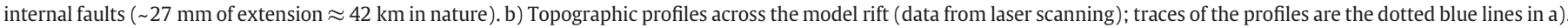

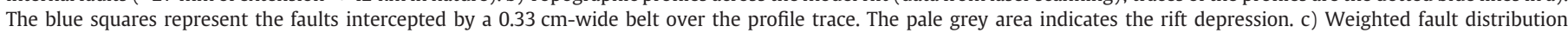
illustrated as $0^{\circ}-180^{\circ}$ histograms at $5^{\circ}$ intervals. 

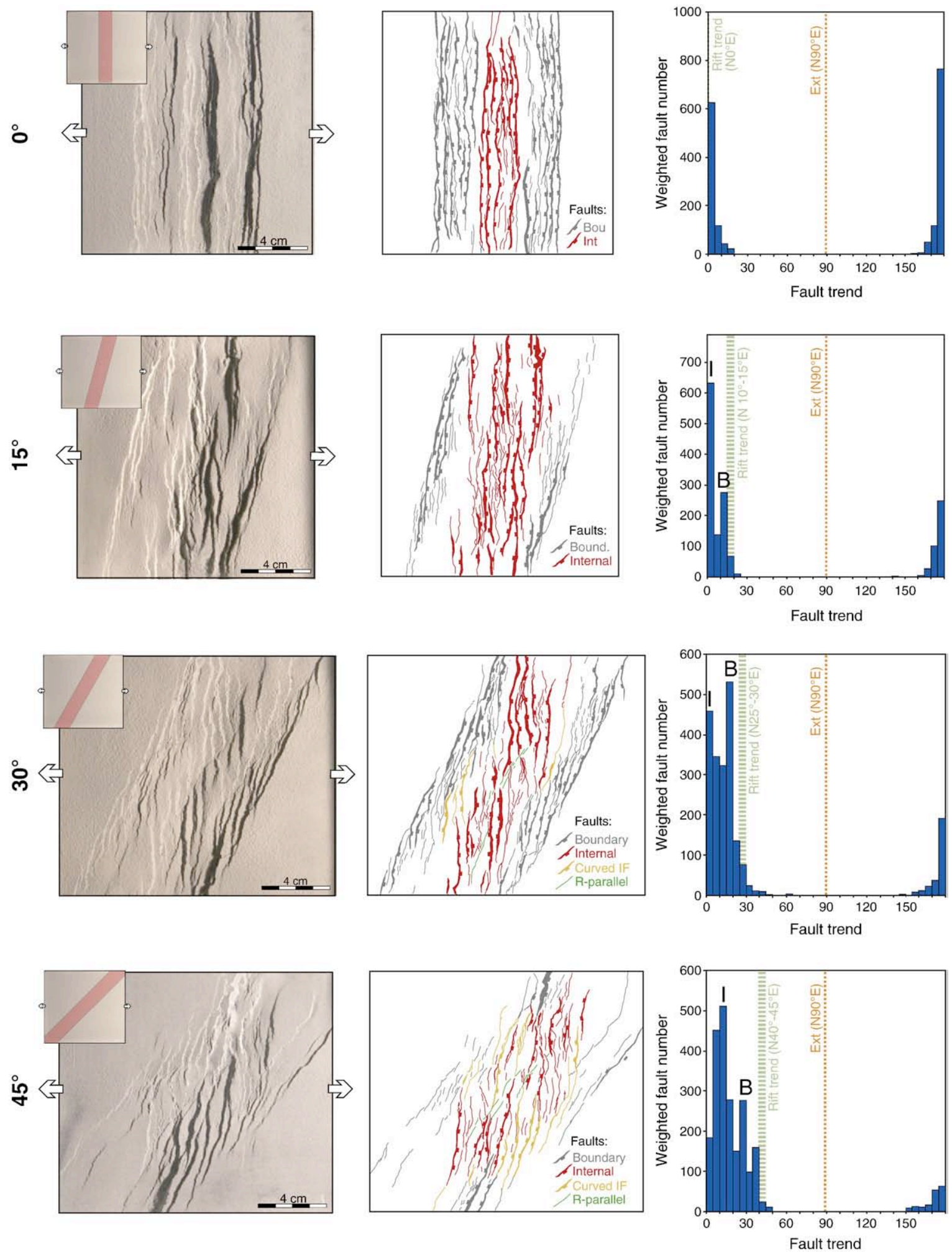

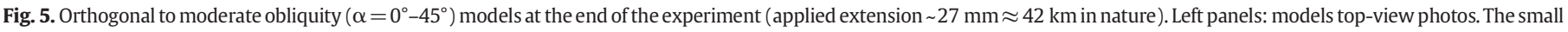

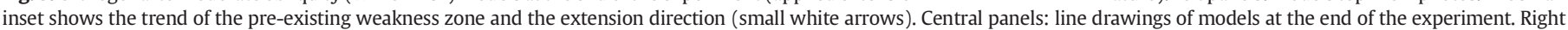

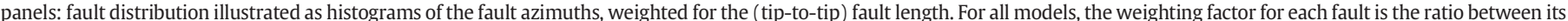

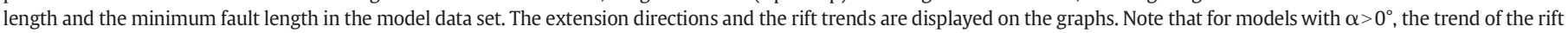

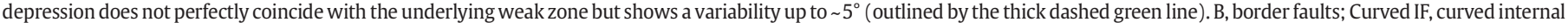
faults; I, internal faults; R-parallel, rift parallel-faults.

of deformation from the rift borders toward the rift centre. For increasing extension, internal faults increasingly accommodated deformation and the activity of boundary faults consequently reduced. This behaviour characterizes the second evolutionary phase (Stage 2 in Fig. 4a). In orthogonal extension and low obliquity models ( $\alpha$ from $0^{\circ}$ to $30^{\circ}$ ), the internal faults developed during the second stage were orthogonal to the extension direction (main orientation peak around $\mathrm{N}^{\circ}-05^{\circ}$ ), whereas these faults 
were slightly oblique in moderate obliquity models (peak around N10 $-15^{\circ}$; Fig. 5).

In low and moderate obliquity models the internal faults were arranged in two en-echelon segments linked by a complex transfer zones, where rift-parallel faults were observed (R-parallel in Fig. 5). For $\alpha=30^{\circ}$ and $\alpha=45^{\circ}$ the last extension steps led the internal faults to further propagate and interact with the rift margins, acquiring a S-shape geometry to adjust with the border faults (Curved IF in Fig. 5).

It is worth noting that the orientation peaks of boundary and internal faults did not change during model evolution (Fig. 4c). Rather, as extension increased the difference between the statistical weight of the internal and the border fault peaks decreased: during the second stage, the number of internal faults notably increased, raising the weight of the corresponding orientation peak. At the same time the border faults strongly reduced their activity, and the relative peak grew slower than that of internal faults (Fig. 4c). Accordingly, the fault length analysis shows an overall increase in the average value of border fault length as the obliquity angle $\alpha$ decreased (Fig. 5).

Low obliquity models were characterized by a clear partitioning between the model rift margins and the rift floor: the rift margins displayed a strike-slip component of motion, whereas nearly pure dip-slip faults affected the rift floor. In moderate obliquity $\left(\alpha=45^{\circ}\right)$ deformation partitioning between the margins and the rift floor was less marked since the internal faults were not orthogonal to the direction of extension and, together with the boundary faults, accommodated a component of the strike-slip deformation.

Finally, the comparison of the different models suggests that the timing of the transition from the first to the second evolutionary stage was a function of the obliquity angle $\alpha$ : the first internal faults developed earlier in moderate obliquity models (i.e. a minor amount of bulk extension was needed) and comparatively later for low obliquity and orthogonal rifting model (i.e. a major amount of bulk extension was required). This suggests that models with different obliquity showed a different evolutionary stage of rifting even if they experienced an equal amount of bulk extension (see Fig. S4).

\section{Discussion}

The comparison between fault architecture in the different MER sectors with the characteristics of deformation shown by the lithospheric-scale analogue models provides new insights on the time-space evolution of continental rifting in Ethiopia and allows speculating on the plate kinematics driving the extensional deformation. Whereas previous works have compared the results of analogue models either with the MER fault pattern as a whole (Bonini et al., 1997) or considering two main sectors only (Corti, 2008), this work presents a complete and more detailed investigation of the four distinct MER sectors.

\subsection{Comparison of fault analysis and analogue models}

The peculiar distribution and architecture of faulting in the different MER sectors (Fig. 1) can be associated with different obliquity models; specifically, the NMER can be compared to the $\alpha=45^{\circ}$ model, the CMER to the $\alpha=30^{\circ}$ model, and the SMERn and SMERs to the $\alpha=15^{\circ}$ and orthogonal extension models, respectively (Figs. 6, 7). The main points of similarity between the rift architecture in models and in the MER sectors are:

1) The analogue models and natural prototype display similar fault patterns, characterized by the two distinct fault families affecting the margins and the rift depression (Fig. 6; Corti, 2008). Both in models and nature, the two fault systems are normally arranged en-echelon, suggesting a strike-slip component of displacement. Typically, the internal faults (WFB faults in nature) are clustered into right-stepping en-echelon segments affecting the rift floor, well expressed in the NMER and in the correspondent $45^{\circ}$ obliquity model (Figs. 2, 6).

2) The two-stage model evolution (Fig. 4) mimics the diachronous activation of border faults and internal Wonji faults during the Late Miocene-Early Pliocene and Late Pliocene(?)-Early Pleistocene, respectively (at least in the NMER). The timing of deformation evolution in the MER is consistent with that of analogue models (Fig. 6). Deactivation of boundary faults and appearance of Wonji faults occur early (at the Pliocene-Quaternary boundary) in the NMER, consistent with rapid shift of deformation to the rift floor in the $45^{\circ}$-obliquity model (Fig. 6). Migration of deformation in this rift sector occurred after $\sim 20 \mathrm{~km}$ of bulk extension (e.g., Corti, 2008), strikingly fitting the predictions based on the moderateobliquity modelling results (see Agostini et al., 2009). Conversely, strong Quaternary boundary fault activity and Wonji faults in the initial stages of development and propagation testify that extensional strain is mostly localised at the margins of the rift depression in the CMER and SMER, in agreement with a prolonged phase of boundary faulting and later development of internal faults in the corresponding orthogonal and low-obliquity models (Fig. 6).

3) The main fault orientation peaks in each analogue model ( $\alpha$ varying from $0^{\circ}$ to $45^{\circ}$ ) are best fitted to the fault peaks in the corresponding MER sector after an invariable $10^{\circ}$ clockwise rotation (Fig. 7). After such a rotation the histograms of model fault distribution coincide with those of the corresponding MER sectors supporting the robustness of this approach. Notably, both in models and nature, the boundary fault system has an overall trend that is parallel to the rift axis, although single faults are oblique to this trend (Fig. 7). The internal faults orientation display an equivalent along-axis variability controlled by the $\alpha$ angle both in models and nature. Particularly, they are perpendicular to the inferred direction of extension in the CMER and SMER, as well as in the corresponding low-obliquity $\left(\alpha=15^{\circ}-30^{\circ}\right)$ and orthogonal $\left(\alpha=0^{\circ}\right)$ models, whereas they trend oblique in the NMER and in the $45^{\circ}$-obliquity model, forming a $\sim 10^{\circ}-$ $15^{\circ}$ angle with the orthogonal to the stretching vector (Fig. 7).

A discrepancy between models and nature is related to the $\mathrm{N} 100^{\circ}-$ $130^{\circ}$-trending cluster of faults observed in the SMERs histogram, which was not reproduced in the corresponding orthogonal extension $\left(\alpha=0^{\circ}\right)$ model (Fig. 7). These faults likely represent inherited structural trends reactivated during the rifting (e.g., Corti, 2009). Since models are not pre-deformed, they cannot account for similar structures.

4) In moderate obliquity models $\left(\alpha=45^{\circ}\right)$ inward migration of deformation occurs at the early stages of extension, implying that internal faults increasingly accommodates the extensional strain and the border faults are progressively deactivated. Analogously, in the NMER the main fault peak corresponds to the WFB that dominantly accommodate extension, whereas the border faults are characterized by a lower statistical weight consistent with them being inactive and eroded, as indicated by geological data and historic and current seismicity (Keir et al., 2006, 2009; Wolfenden et al., 2004). Conversely, in models with $\alpha \leq 30^{\circ}$ later inward migration of faulting implies that border faults accommodate a significant portion of deformation throughout the model evolution. This accords with the higher statistical weight of the border faults over the WFB in the CMER and SMER, where seismicity data indicates the border faults to be tectonically active (Keir et al., 2006).

5) Both in the MER and in the models, the angle between internal and border faults is a function of the rift trend (i.e., the rift obliquity), and this angle increases as the obliquity angle $\alpha$ increases (Fig. S5). Moreover, both MER sectors and models show an overall increase of the total span of fault orientation (azimuth spectrum) with increasing rift obliquity (Fig. S5). This is also testified by the standard deviation values of the weighted fault azimuth distribution (Table S2). Higher values of azimuth dispersion obtained from 


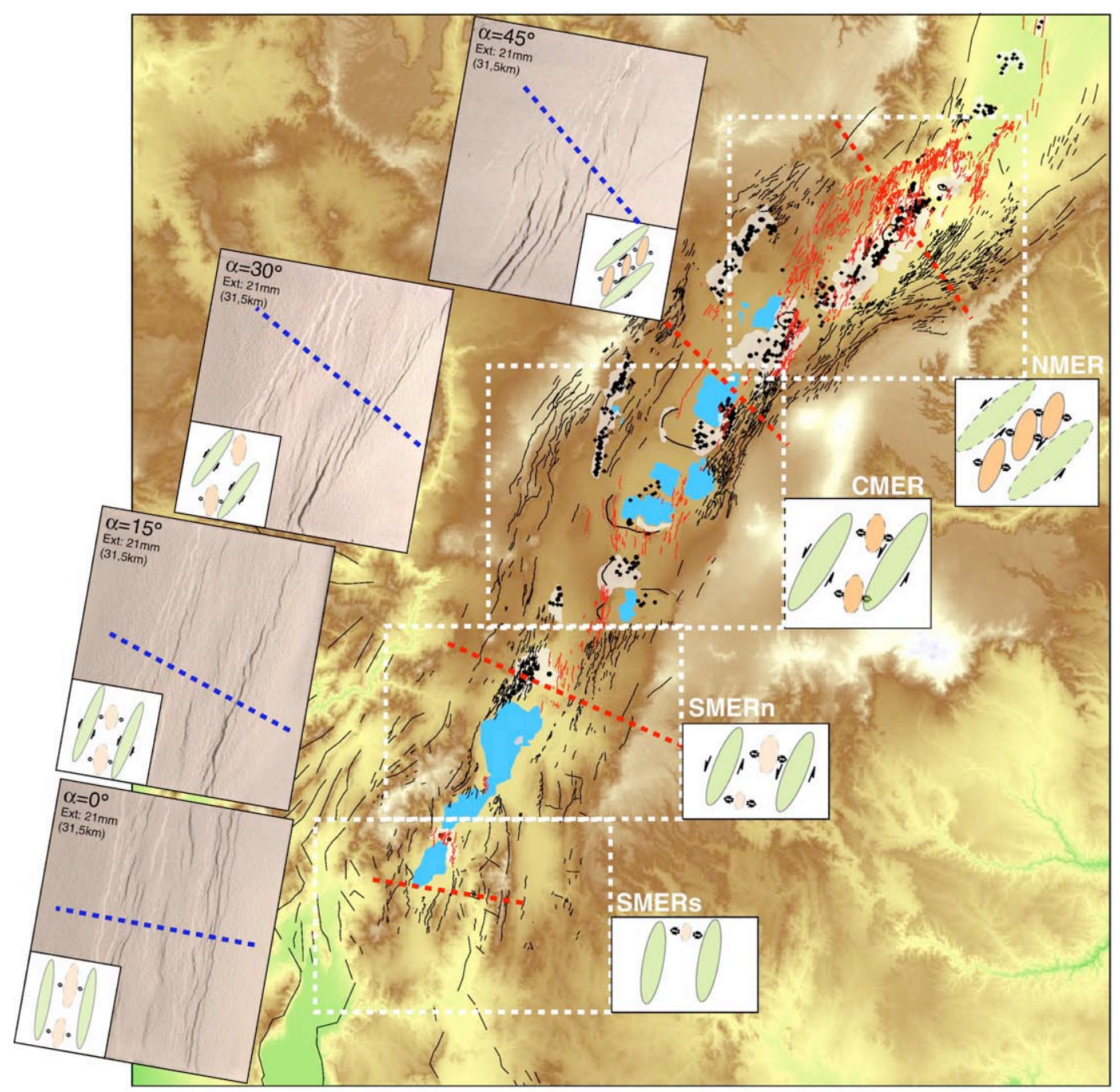

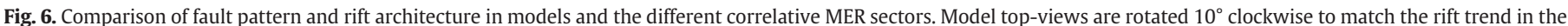

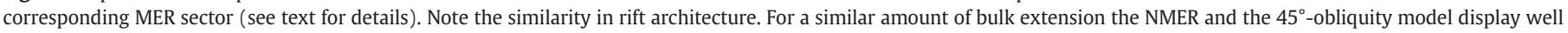

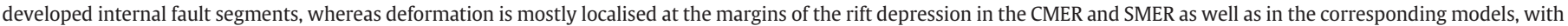
internal faults in the initial stages of development and propagation. Red and blue dashed lines show the traces of the profiles illustrated in Figure 9.

the SMERs data are attributable to the influence of pre-existing basement structures that are largely exposed in this area, and to the superimposition of the present kinematics onto previous deformative stages, possibly related to an early northward propagation of the Kenya Rift at 20-21 Ma (Bonini et al., 2005).

6) The length of model boundary faults increases from $\alpha=45^{\circ}$ to $\alpha=0^{\circ}$ (see Section 3.3), and, in a similar fashion, border fault length increases from the NMER to the SMER (see Section 3.2.1 and Table S1).

\subsection{Implication for the Nubia-Somalia kinematics}

The $10^{\circ}$ clockwise rotation that each model requires to match the average trend of the corresponding MER sector faults results in an overall $\mathrm{N} 100^{\circ} \mathrm{E}$ direction of extension between the opposite sides of each model (Fig. 8). This direction is in very good agreement with the results of geodetic measurements that indicates a current $\sim \mathrm{N} 100^{\circ} \pm 5^{\circ}$ extension vector between Nubia and Somalia plates (e.g. Bendick et al., 2006; Stamps et al., 2008), as well as it agrees with paleostress and geological data (Bonini et al., 2005; Casey et al., 2006; Pizzi et al., 2006) and plate motion analysis (Chu and Gordon, 1999; Horner-Johnson et al., 2007; Fig. 8).
In the analogue modelling the applied kinematics was kept constant during the experiment and thus controlled the two-phase rift evolution (Fig. 4). This suggests that a constant $\sim \mathrm{N} 100^{\circ} \mathrm{E}$ motion between Nubia and Somalia plates could have acted since the onset of rifting in the MER, and thus could have controlled the diachronous activation of boundary and Wonji faults (Corti, 2008). This interpretation has a relevance for the pre 3.2 Ma kinematics of major plates, which would have been constant over the past $11 \mathrm{My}$, implying a long lasting oblique rifting in the Miocene to Recent MER history.

\subsection{Evolution of the different MER sectors}

The differences observed in the fault pattern and in the distribution of deformation along the MER, coupled with the results of analogue modelling, suggest an along-axis variation in rift evolution (Figs. 6, 9).

The NMER fault pattern is characterized by well developed WFB fault segments that affect the rift floor and accommodate approximately the $80 \%$ of the current extensional deformation (Billham et al., 1999), which is manifested by the dominant statistical weight of WFB structures (Fig. 2, 7). On the contrary, the boundary faults are generally deactivated and eroded thereby showing a subordinate 

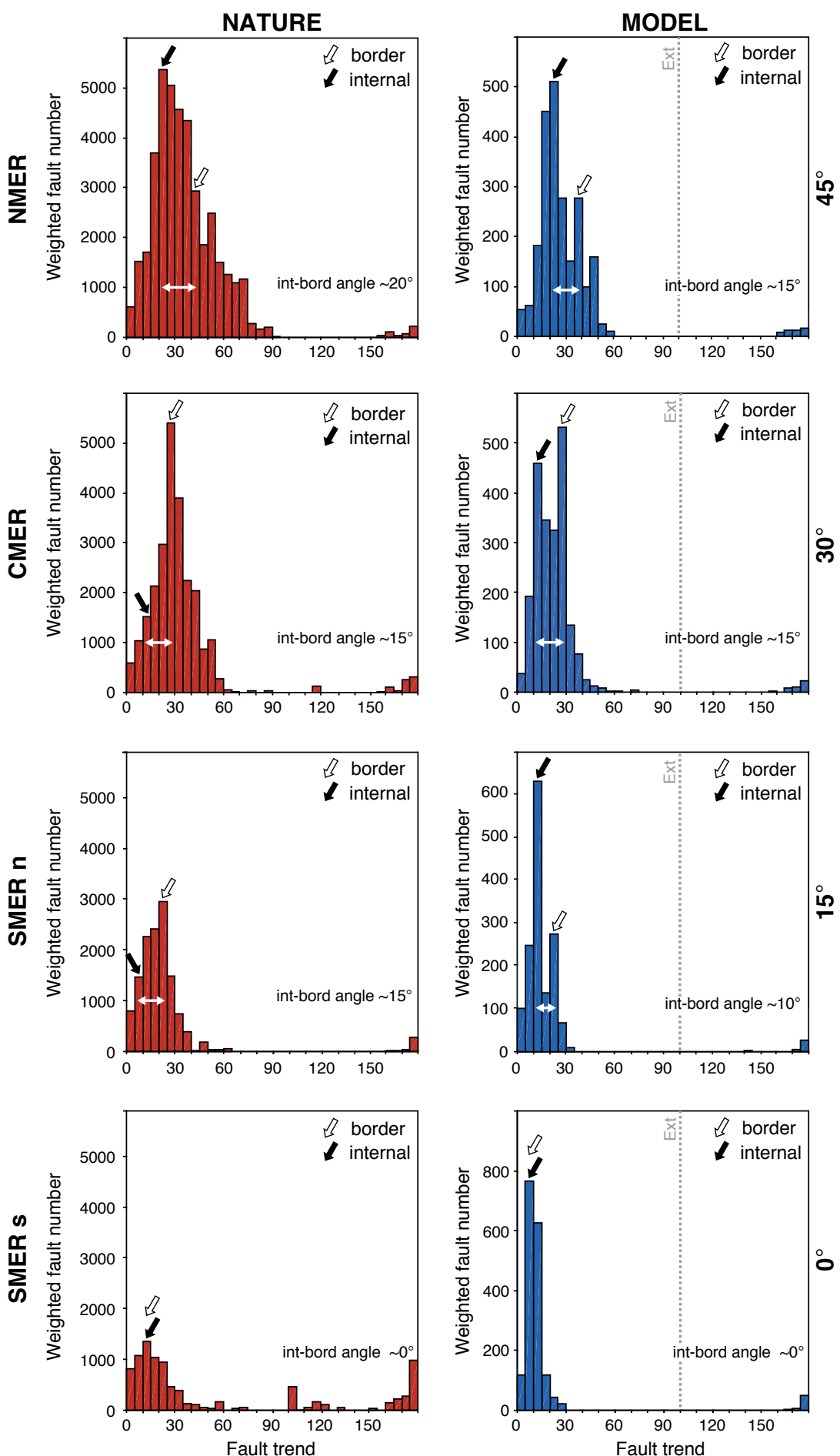

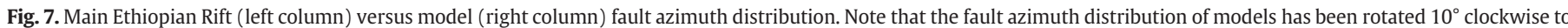

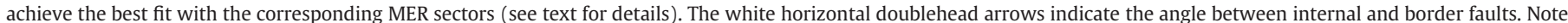

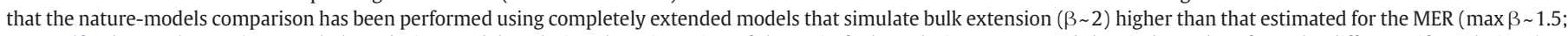

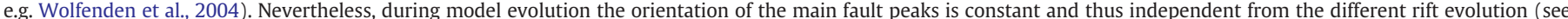

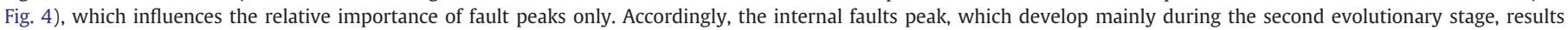
comparatively higher in models than in the MER.

statistical importance. These characteristics accord with the fault pattern and the distribution of deformation that is typical of stage 2 of model evolution (Fig. 4), that is when a model has already experienced the inward migration of the deformation. On this basis, the NMER can be considered as a mature rift. These findings are supported by geophysical data that point to a NMER lithosphere extensively modified by magmatic processes and that can be considered in a transitional stage between completely continental and oceanic lithosphere (Rooney et al., 2007). The NMER lithosphere is in fact characterized by a relatively thin crust, which thickens southward to the boundary with the CMER (e.g. Maguire et al., 2006), and a strong magma upraising and accumulation throughout the lithosphere in correspondence of the tectono-magmatic WFB segments (e.g. Kendall et al., 2005; Keranen et al., 2004). Although recent 


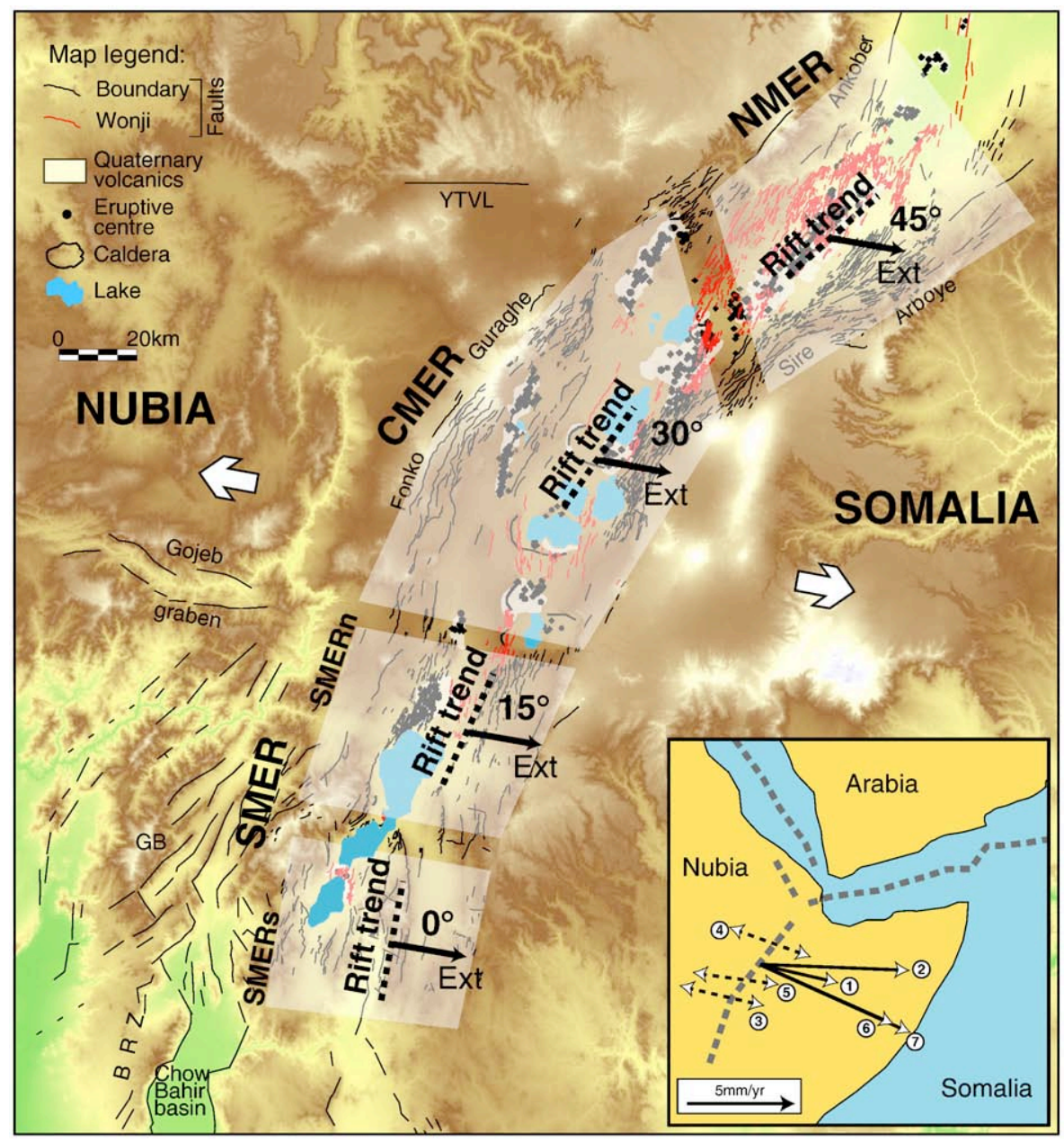

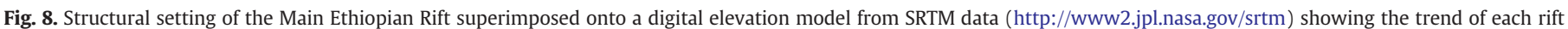

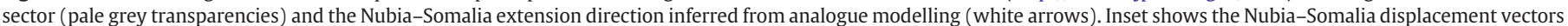

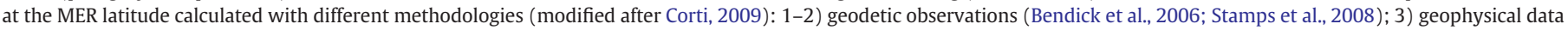
(Keir et al., 2006); 4-5) geological data (Casey et al., 2006; Pizzi et al., 2006); 6-7) plate motion data (Horner-Johnson et al., 2007). Abbreviations are as in Figure 1.

models have emphasized the role of magma in the localization of deformation within the WFB of NMER (magma-assisted rifting of Kendall et al., 2005), the development of internal faults in analogue models - that do not consider the role of magma in the deformation process - suggests the primary control of tectonics on rift evolution (Corti, 2008). In agreement with this observation, despite the magmaassisted model implies internal WFB segments to form orthogonal to the regional extension vector, the orientation peak of $\alpha=45^{\circ}$ model internal faults strikingly matches the corresponding WFB peak and both are slightly oblique $\left(<10^{\circ}-15^{\circ}\right)$ to the orthogonal to the extension vector (see Section 4.1). We thus suggest the architecture and evolution of WFB to be independent of magmatic processes (Corti, 2008); rather the WFB structures focus a passive uprising of the magma (e.g. Boccaletti et al., 1999).

By reference to the low obliquity $\left(\alpha=30^{\circ}\right)$ model, the internal faults of the CMER, which are mostly concentrated near the rift margins, could represent incipient WFB faults propagating from the rift borders, or, in some cases, remnants of marginal grabens, such as for the Butajira area (Fonko-Guraghe western margin, Fig. 1). The predominance of the border faults, their current tectonic activity (Keir et al., 2006) and the incipient nature of the internal faults suggest that the CMER sector is in a transitional stage correlatable to the "intermediate" evolutionary stage outlined by the analogue models (Figs. 4, 9). In the SMERn and the SMERs, the scarcity of faults in the rift floor and the concentration of the deformation at the rift borders (Figs. 2, 9) indicate that such sectors are in an early evolutionary stage similar to Stage 1 of model evolution (Fig. 4).
The less evolved nature of the CMER and the SMER sectors is also reflected by the lithospheric characteristics, in particular by a lower crustal thinning and less advanced magmatic modifications with respect to the NMER (e.g. Keranen and Klemperer, 2008). Particularly, the CMER lithosphere can be considered as a continental lithosphere poorly modified by magmatic processes, while the lithosphere is considered to be completely continental in the less evolved SMER (Rooney et al., 2007). Thus, a strong correspondence between the along-axis different rift progression and the distinct lithospheric characteristics of each MER sector and its magmatic evolution can be highlighted (Corti, 2009, and references therein).

Overall, the extrapolation of analogue model results to nature shows that rift obliquity exerts an important control in how strain is distributed in the upper crust as extension proceeds: for the same amount of bulk extension and similar lithospheric thinning, models with different obliquity display different evolutionary stages. In the NMER, higher rift obliquity favors a rapid evolution of the rift process, with early abandonment of boundary faults and consequent early shift of deformation to the Wonji faults within the rift floor. The thinner crust characterizing this rift sector $(\sim 25 \mathrm{~km})$ with respect to the CMER ( $35 \mathrm{~km}$; Maguire et al., 2006$)$ apparently requires the action of additional factors, which are most likely mantle plumerelated thermal erosion (Dugda et al., 2007) and Oligo-Miocene rifting between Arabia and Africa related to an early triple junction tectonics (e.g., Wolfenden et al., 2004). Conversely, in the CMER and SMER lower obliquity may prolong boundary faults activity and retard the 

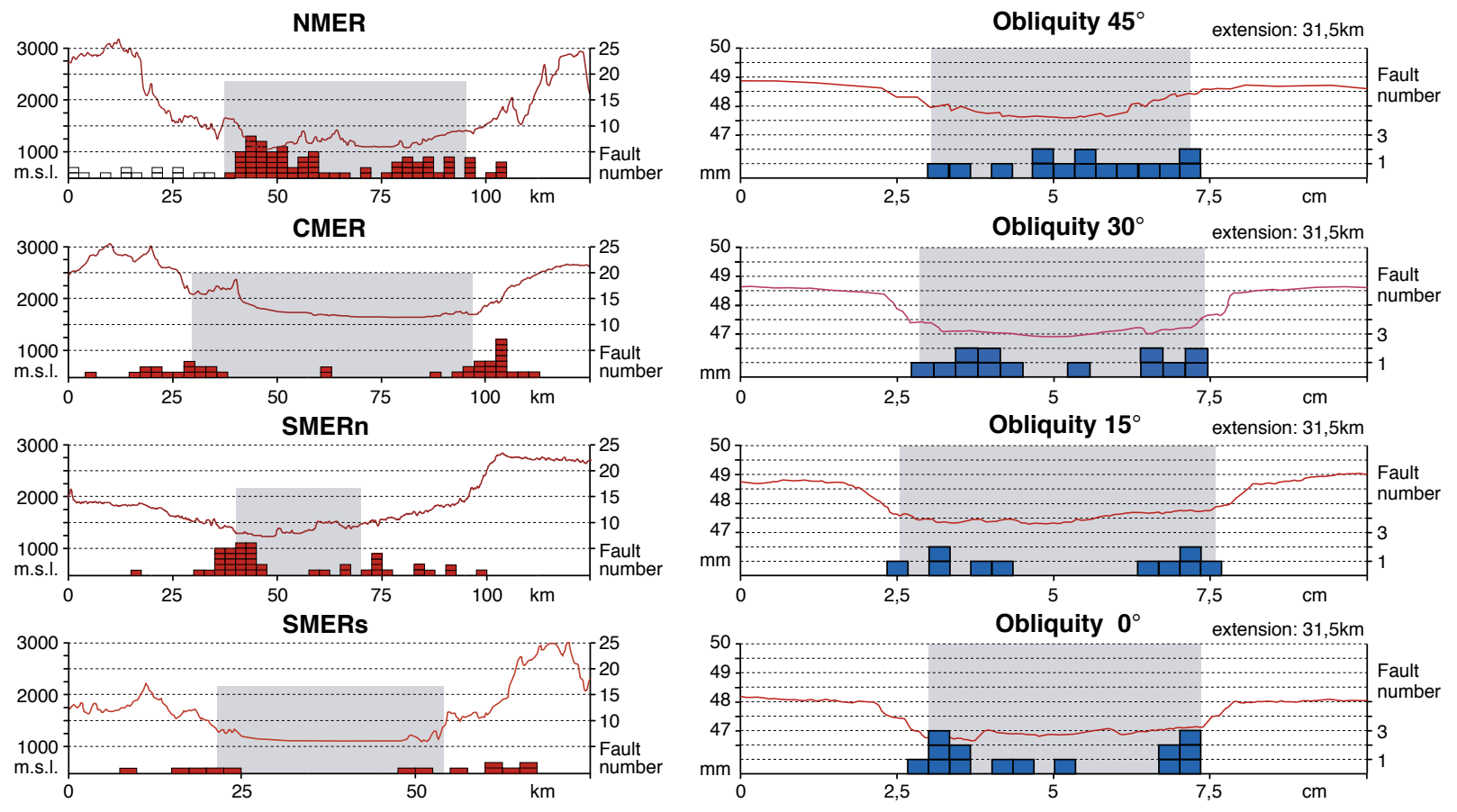

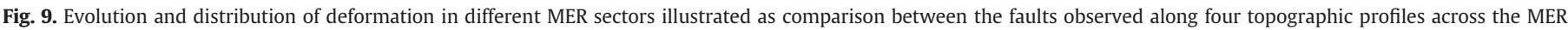

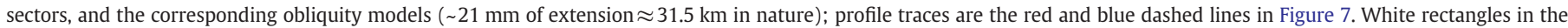

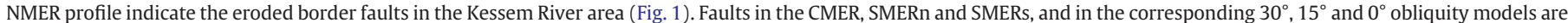

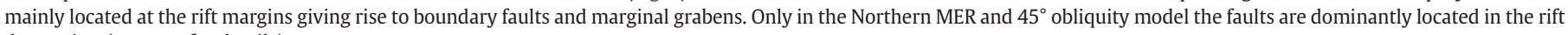
depression (see text for details).

shift of tectonic activity to the rift depression. Thus, application the modelling results to nature suggests that the north-to-south differences in rift obliquity may contribute to the along-axis variations in rift architecture and evolution. The effect of a southward rift propagation from the Southern Afar to the SMER (Bonini et al., 2005) - presumably controlled by large scale kinematics of Africa plate (e.g., Ebinger, 2005) - represents an additional key factor promoting the inferred southward-decreasing rift development.

\section{Inferences on continental rifting progression from the Main Ethiopian Rift}

The MER offers a complete record of the time-space evolution of a continental rift, from its early stages (SMER) to the more evolved stages (NMER), and thus represents a key area where analysing the evolution of continental rifting (e.g. Ebinger, 2005; Hayward and Ebinger, 1996).

The analysis of the brittle deformation distribution in the MER performed on a new structural database and its comparison with the results of lithospheric analogue models has allowed us to suggest that the pattern of brittle deformation in the upper crust has been strongly influenced by oblique rifting conditions since its birth in the Late Miocene, related to a constant post ca. $11 \mathrm{Ma}$ and $\sim \mathrm{N} 100^{\circ}$ E-directed Nubia-Somalia motion. The different MER sectors currently record and may exemplify the typical evolution of continental narrow rifts, as outlined in Figure 10.

The rift evolution begins with the definition of a main subsiding basin and the development of faults on the depression boundaries in response to the horizontal pull exerted by plate-driving forces. This early fault-dominated continental rifting stage is peculiar to the present Southern MER sectors (Fig. 10a). As the system evolves, deformation migrates from the margins, where boundary faults are still active, toward the centre of the rift depression where incipient internal faults start forming (Fig. 10b). This is characteristic of the transitional rifting stage, as can be identified in the CMER, where young faults affecting the rift floor may be observed and associated with incipient WFB migrating from the rift borders. With increasing rift evolution, the system evolves toward an incipient continental rupture stage, as exemplified by the NMER sector (Fig. 10c). At this stage most of the volcano-tectonic activity is focused on the magmatic segments located inside the rift depression (e.g. Ebinger, 2005). Our model suggests that the migration of deformation is primarily controlled by the oblique rifting kinematics (and the variable obliquity angle in the different rift sectors), allowing interpreting the localization of the magmatic activity along the internal WFB faults as a passive feature. However, as the process evolves, a positive feedback is established between strain localization and magma upraising eventually leading to a magma-assisted rifting in which magma weakens the lithosphere and increasingly controls the largest part of the deformation (e.g. Beutel et al., 2010; Buck, 2004; Ebinger, 2005; Keir et al., 2006; Kendall et al., 2005). Magma supply and diking prevents the increasing of the stresses to a level able to activate the border faults, which consequently reduce or cease their activity (Buck, 2004). These conditions mark the transitional stage between continental rifting and seafloor spreading, where the crust and lithosphere are strongly modified by magmatism and new crust is formed in correspondence to the large crustal magmatic bodies of the tectono-magmatic segments (e.g. Keranen et al., 2004). At this stage the WFB segments in the NMER act as incipient spreading centres, with crustal characteristics (i.e. magmatic intrusions and diking) and en-echelon arrangement mimicking the structure and second-order segmentation of oceanic slow-spreading ridges (e.g. Hayward and Ebinger, 1996).

As a general implication, the results of analogue modelling support that the different stages of rift evolution outlined above may be reached for similar amounts of bulk extension and lithospheric thinning depending on rift obliquity. Our analysis suggests indeed that migration of deformation, in-rift fault development, and the successive focusing of magmatic activity with associated thermomechanical modification of the extending lithosphere develop earlier with increasing obliquity, eventually leading to a faster break-up of 
a

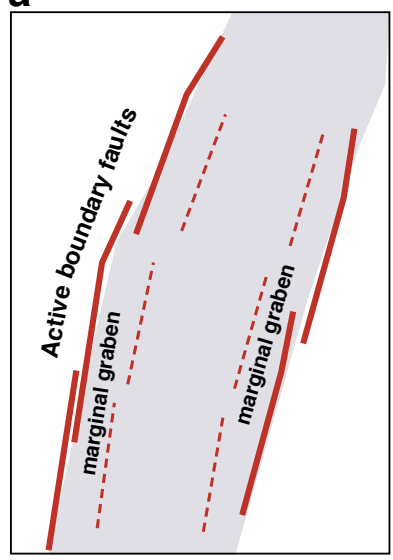

Early continental rifting b

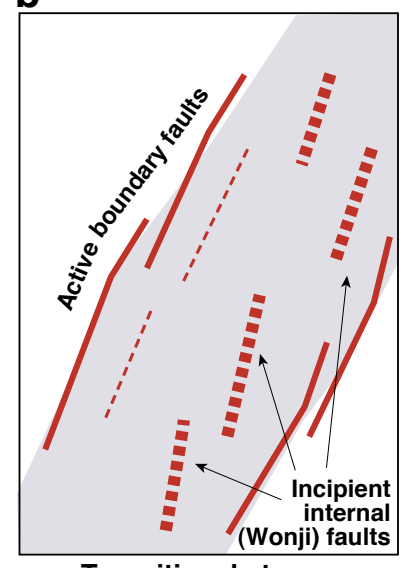

Transitional stage c

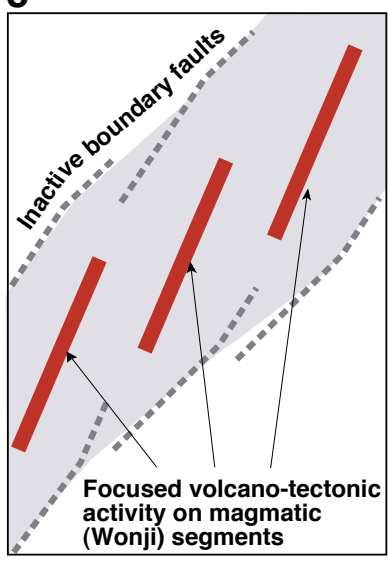

Incipient continental rupture

\section{INCREASING RIFT EVOLUTION}

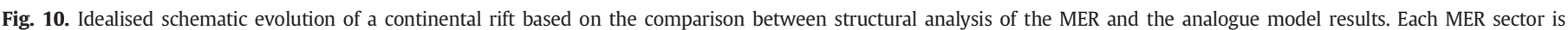

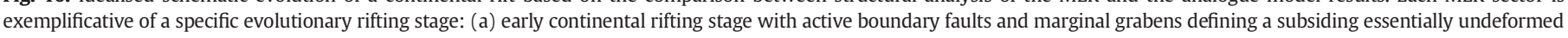

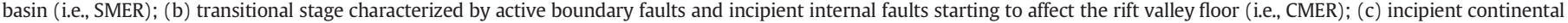
rupture stage where deformation is mainly accommodated by volcano-tectonic segments inside the rift depression (i.e., NMER).

the continental lithosphere. The observation that in the NMER the break-up stage has been reached at relatively small stretching factors and for thick crust (up to $30-35 \mathrm{~km}$ ) without the reduction in crustal thickness observed in other oceanized rift settings (e.g., Woodlark Rift in Papua-New Guinea, where crustal thickness is only $16-18 \mathrm{~km}$; see Daly et al., 2008) supports this observation. In conclusion, we suggest that rift obliquity is an additional key player in controlling rift evolution together with other well known factors, such as the amount of stretching, lithospheric thinning, and the availability of basaltic melts (e.g. Ebinger, 2005; Ziegler and Cloetingh, 2004).

Supplementary materials related to this article can be found online at doi:10.1016/j.epsl.2010.11.024.

\section{Acknowledgments}

We thank Derek Keir and two anonymous reviewers for the detailed, constructive comments that helped to improve the manuscript. We also thank Antonio Zeoli for the technical assistance during satellite image and digital elevation model elaboration and Ilaria Isola for density map elaboration. Research supported by CNR Funds (RSTL no. 105 "Evoluzione della parte Nord del rift Afroarabico e distribuzione regionale delle georisorse”; P.I. M. Bonini).

\section{References}

Abebe, B., Boccaletti, M., Mazzuoli, R., Bonini, M., Tortrici, L., Trua, T., 1999. Geologica Map of the Lake Ziway-Asela region (Main Ethiopian Rift). Scale 1:50, 000. A.R.C.A., Firenze.

Abebe, T., Manetti, P: Bonini, M., Corti, G., Innocenti, F., Mazzarini, F., and Pècksay, Z., 2005. Geological map (scale 1:200.000) of the northern Main Ethiopian Rift and its implications for the volcano-tectonic evolution of the rift: Geological Society of America Map and Chart MCH094, 20p. doi:10.1130/2005MCH094TXT.

Abebe, B., Acocella, V., Korme, T., Ayalew, D., 2007. Quaternary faulting and volcanism in the Main Ethiopian Rift. J. Afr. Earth Sci. 48, 115-124.

Agostini, A., Corti, G., Zeoli, A., Mulegeta, G., 2009. Evolution, pattern and partitioning of deformation during oblique continental rifting: Inferences from lithosphericscale centrifuge models. Geochem. Geophys. Geosyst. 10, Q11015. doi:10.1029/ 2009GC002676.

Bastow, I.D., Nyblade, A.A., Stuart, G.W., Rooney, T.O., Benoit, M.H., 2008. Upper mantle seismic structure beneath the Ethiopian hot spot: rifting at the edge of the African low-velocity anomaly. Geochem. Geophys. Geosyst. 9, Q12022. doi:10.1029/ 2008GC002107.

Bendick, R., Bilham, R., Asfaw, L., Klemperer, S., 2006. Distributed Nubia-Somalia relative motion and dyke intrusion in the main Ethiopian rift. Geophys. J. Int. 165 (1), 303-310.
Beutel, E., van Wijk, J., Ebinger, C., Keir, D., Agostini, A., 2010. Formation and stability of magmatic segments in the Main Ethiopian and Afar rifts. Earth Planet. Sci. Lett. 293, 225-235. doi:10.1016/j.epsl.2010.02.006.

Billham, R., Bendick, R., Larson, K., Braun, J., Tesfaye, S., Mohr, P., Asfaw, L., 1999. Secular and tidal strain across the Ethiopian rift. Geophys. Res. Lett. 27, 2789-2984.

Boccaletti, M., Bonini, M., Mazzuoli, R., Abebe, B., Piccardi, L., Tortorici, L., 1998. Quaternary oblique extensional tectonics in the Ethiopian Rift (Horn of Africa). Tectonophysics 287, 97-116.

Boccaletti, M., Mazzuoli, R., Bonini, M., Trua, T., Abebe, B., 1999. Plio-Quaternary volcano-tectonic activity in the northern sector of the Main Ethiopian Rift (MER): relationships with oblique rifting. J. Afr. Earth Sci. 29, 679-698.

Bonini, M., Souriot, T., Boccaletti, M., Brun, J.P., 1997. Successive orthogonal and oblique extension episodes in a rift zone: laboratory experiments with application to the Ethiopian Rift. Tectonics 16, 347-362.

Bonini, M., Corti, G., Innocenti, F., Manetti, P., Mazzarini, F., Abebe, T., Pecskay, Z., 2005. The evolution of the Main Ethiopian Rift in the frame of Afar and Kenya rifts propagation. Tectonics 24, TC1007. doi:10.1029/2004TC001680.

Brun, J.-P., Tron, V., 1993. Development of the North Viking Graben: inferences from laboratory modelling. Sed. Geol. 86, 31-51.

Buck, W.R., 2004. Consequences of asthenospheric variability on continental rifting. In: Karner, G.D., et al. (Ed.), Rheology and Deformation of the Lithosphere at Continental Margins. Columbia Univ. Press, New York, pp. 1-30.

Casey, M., Ebinger, C.J., Keir, D., Gloaguen, R., Mohamad, F., 2006. Strain accommodation in transitional rifts: extension by magma intrusion and faulting in Ethiopian rift magmatic segments. In: Yirgu, G., Ebinger, C.J., Maguire, P.K.H. (Eds.), The Afar Volcanic Province within the East African Rift System: Geol. Soc. Spec. Publ., 259, pp. 143-163.

Chu, D., Gordon, R.G., 1999. Evidence for motion between Nubia and Somalia along the Southwest Indian Ridge. Nature 398, 64-67.

Corti, G., 2008. Control of rift obliquity on the evolution and segmentation of the main Ethiopian rift. Nat. Geosci. 1, 258-262.

Corti, G., 2009. Continental rift evolution: from rift initiation to incipient break-up in the Main Ethiopian Rift, East Africa. Earth Sci. Rev. 96, 1-53.

Daly, E., Keir, D., Ebinger, C.J., Stuart, G.W., Bastow, I.D., Ayele, A., 2008. Crustal tomographic imaging of a transitional continental rift: the Ethiopian rift. Geophys. J. Int. 172, 1033-1048.

Dauteuil, O., Brun, J.P., 1996. Deformation partitioning in a slow spreading ridge undergoing oblique extension: Mohns Ridge, Norwegian Sea. Tectonics 15, 870-884.

Dauteuil, O., Huchon, P., Quemeneur, F., Souriot, T., 2001. Propagation of an oblique spreading centre: the western Gulf of Aden. Tectonophysics 332, 423-442.

Dugda, M., Nyblade, A.A., Julia, J., 2007. Thin lithosphere beneath the Ethiopian plateau revealed by a joint inversion of Rayleigh wave group velocities and receiver functions. J. Geophys. Res. 112. doi:10.1029/2006JB004918.

Ebinger, C., 2005. Continental breakup: the East African perspective. Astron. Geophys. 46, 2.16-2.21.

Ebinger, C.J., Casey, M., 2001. Continental breakup in magmatic provinces: an Ethiopian example. Geology 29, 527-530.

Ebinger, C.J., Yemane, T., WoldeGabriel, G., Aronson, J.L., Walter, R.C., 1993. Late EoceneRecent volcanism and faulting in the southern main Ethiopian rift. J. Geol. Soc. Lond. 150, 99-108.

Gouin, P., 1979. Earthquake history of Ethiopia and the Horn of Africa. IDRC, Ottawa. $258 \mathrm{pp}$. 
Hayward, N.J., Ebinger, C.J., 1996. Variations in the along-axis segmentation of the Afar Rift system. Tectonics 15, 244-257.

Horner-Johnson, B.C., Gordon, R.G., Argus, D.F., 2007. Plate kinematic evidence for the existence of a distinct plate between the Nubian and Somalian plates along the Southwest Indian Ridge. J. Geophys. Res. 112, B05418. doi:10.1029/2006JB004519.

Kazmin, V., 1978. Geological Map of sheet NC37-15, Nazret, Ethiopia. Scale 1:250, 000. Ethiopian Institute of Geological Surveys. Ministry of Mines, Energy and Water Resources. Printed by Ethiopian Mapping Agency, Addis Ababa, Ethiopia.

Keir, D., Kendall, J.-M., Ebinger, C.J., Stuart, G.W., 2005. Variations in late syn-rift melt alignment inferred from shear-wave splitting in crustal earthquakes beneath the Ethiopian rift. Geophys. Res. Lett. 32, L23308. doi:10.1029/2005GL024150.

Keir, D., Ebinger, C.J., Stuart, G.W., Daly, E., Ayele, A., 2006. Strain accommodation by magmatism and faulting as rifting proceeds to breakup: seismicity of the northern Ethiopian rift. J. Geophys. Res. 111 (B5), B05314. doi:10.1029/2005JB003748.

Keir, D., Bastow, I.D., Whaler, K.A., Daly, E., Cornwell, D.G., Hautot, S., 2009. Lower crustal earthquakes near the ethiopian rift induced by magmatic processe. Geochem. Geophys. Geosyst. 10, 1-10. doi:10.1029/2009GC002382.

Kendall, J.M., Stuart, G.W., Ebinger, C.J., Bastow, I.D., Keir, D., 2005. Magma assisted rifting in Ethiopia. Nature 433, 146-148.

Keranen, K., Klemperer, S.L., 2008. Discontinuous and diachronous evolution of the Main Ethiopian Rift: implications for the development of continental rifts. Earth Planet. Sci. Lett. 265, 96-111. doi:10.1016/j.epsl.2007.09.038.

Keranen, K., Klemperer, S.L., Gloaguen, R., Eagle working group, 2004. Threedimensional seismic imaging of a protoridge axis in the Main Ethiopian rift. Geology 32, 949-952.

Keranen, K., Klemperer, S.L., Julia, J., Lawrence, J.L., Nyblade, A., 2009. Low lower-crustal velocity across Ethiopia: is the Main Ethiopian Rift a narrow rift in a hot craton? Geochem. Geophys. Geosyst. 10, Q0AB01. doi:10.1029/2008GC002293.

Le Turdu, C., Tiercelin, J., Gibert, E., Travi, Y., Lezzar, K.E., Richert, J.P., Massault, M., Gasse, F., Bonnefille, R., Decobert, M., Gensous, B., Jeudy, V., Tamrat, E., Mohammed, M.U., Martens, K., Atnafu, B., Chernet, T., Williamson, D., Taieb, M., 2005. The Ziway-Shala Lake basin system, Main Ethiopian Rift: influence of volcanism, tectonics, and climatic forcing on basin formation and sedimentation. Palaeogeogr. Palaeoclimatol. Palaeoecol. 150, 135-177.
Maguire, P.K.H., Keller, G.R., Klemperer, S.L., Mackenzie, G.D., Keranen, K., Harder, S. O'Reilly, B., Thybo, H., Asfaw, L., Khan, M.A., Amha, M., 2006. Crustal structure of the Northern Main Ethiopian Rift from the EAGLE controlled source survey; a snapshot of incipient lithospheric break-up. In: Yirgu, G., Ebinger, C.J., Maguire, P.K.H. (Eds.), The Afar Volcanic Province within the East African Rift System: Geol. Soc. Spec. Publ., vol. 259, pp. 269-291.

Mohr, P.A., 1962. The Ethiopian Rift System. Bull. Geophys. Observ. Addis Ababa 5 33-62.

Mohr, P., 1983. Volcanotectonic aspects of the Ethiopian Rift evolution. Bull. Cent. Rech Elf Aquitaine Explor. Prod. 7, 175-189.

Pizzi, A., Coltorti, M., Abebe, B., Disperati, L., Sacchi, G., Salvini, R., 2006. The Wonji fault belt (main Ethiopian Rift): structural and geomorphological constraints and GPS monitoring. In: Yirgu, G., Ebinger, C.J., Maguire, P.K.H. (Eds.), The Afar Volcanic Province within the East African Rift System: Geol. Soc. Spec. Publ., 259, pp. 191-207.

Rooney, T., Furman, T., Bastow, I., Ayalew, D., Yirgu, G., 2007. Lithospheric modification during crustal extension in the Main Ethiopian Rift. J. Geophys. Res. 112, B10201. doi:10.1029/2006JB004916.

Soliva, R., Schultz, R., 2008. Distributed and localized faulting in extensional settings: insight from the North Ethiopian Rift-Afar transition area. Tectonics 27, TC2003. doi:10.1029/2007TC002148.

Stamps, D.S., Calais, E., Saria, E., Hartnady, C., Nocquet, J.-M., Ebinger, C.J., Fernandes, R.M., 2008. A kinematic model for the East African Rift. Geophys. Res. Lett. 35, L05304. doi:10.1029/2007GL032781.

WoldeGabriel, G., Aronson, J.L., Walter, R.C., 1990. Geology, geochronology, and rift basin development in the central sector of the Main Ethiopia Rift. Geol. Soc. Am. Bull. 102, 439-458.

WoldeGabriel, G., Yemane, T., White, T., Asfaw, B., Suwa, G., 1991. Age of volcanism and fossils in the Burji-Soyoma area, Amaro Horst, southern Main Ethiopian Rift. J. Afr Earth Sci. 13, 437-447.

Wolfenden, E., Ebinger, C., Yirgu, G., Deino, A., Ayale, D., 2004. Evolution of the northern Main Ethiopian rift: birth of a triple junction. Earth Planet. Sci. Lett. 224, 213-228

Ziegler, P.A., Cloetingh, S.A.P.L., 2004. Dynamic processes controlling evolution of rifted basins. Earth Sci. Rev. 64, 1-50. 